Article

\title{
Electric Power Consumption and Current Efficiency of Electrochemical and Electrobiological Rotating Disk Contactors Removing Nutrients from Wastewater Generated in Soil-Less Plant Cultivation Systems
}

\author{
Joanna Rodziewicz, Artur Mielcarek *(D), Wojciech Janczukowicz and Kamil Bryszewski \\ Department of Environment Engineering, Faculty of Geoengineering, University of Warmia and Mazury in \\ Olsztyn, Warszawska 117a, 10-719 Olsztyn, Poland; joanna.rodziewicz@uwm.edu.pl (J.R.); \\ jawoj@uwm.edu.pl (W.J.); kamil.bryszewski@uwm.edu.pl (K.B.) \\ * Correspondence: artur.mielcarek@uwm.edu.pl
}

Received: 4 December 2019; Accepted: 10 January 2020; Published: 12 January 2020

\begin{abstract}
The study was conducted in a one-stage rotating electrobiological disk contactor (REBDC) and a rotating electrochemical disk contactor (RECDC). Synthetic wastewater with characteristics similar to the wastewater from soil-less cultivation of tomatoes was used in the experiment. Current efficiency (CE) values, that express the denitrification performance of bio- and electrochemical reactors, were higher in the electrobiological contactor than in the electrochemical one. Combining biological processes with electrochemical processes in the electrobiological contactor resulted in almost $20 \%$ higher current efficiency in the contactor operated at a density of $0.63 \mathrm{~A} / \mathrm{m}^{2}$ and hydraulic retention time $(\mathrm{HRT})=4 \mathrm{~h}$. The study showed that, in both the electrochemical and the electrobiological contactor, current density increase and hydraulic retention time extension increased electric power consumption (E) during phosphorus compounds removal and simultaneously lowered current efficiency.
\end{abstract}

Keywords: rotating electrochemical disk contactor; rotating electrobiological disk contactor; electric power consumption; current efficiency; wastewater from soil-less plant cultivation systems

\section{Introduction}

In Poland, almost all cultivation of plants with soil-less methods proceeds in open systems, from where the excess of nutrient medium is discharged into the ground or to surface waters. Concentrations of nutrients in wastewater from, e.g., tomato crops, may even reach up to $466 \mathrm{mg} \mathrm{N} / \mathrm{L}$ for nitrate nitrogen and up to $370 \mathrm{mg} \mathrm{P} / \mathrm{L}$ for total phosphorus [1]. Wastewater of this type should not be discharged to the ground nor to natural water without pre-treatment [1,2].

Wastewater from soil-less cultivation systems with typically high concentrations of oxidized forms of nitrogen and phosphorus may be pre-treated in a rotating electrobiological disk contactor (REBDC) or in a rotating electrochemical disk contactor (RECDC) and afterwards discharged to natural water, ground, or to sewerage facilities [3]. In the case of REBDC, the flow of electric current through this bed ensures good conditions for the simultaneous removal of phosphorus and nitrates mainly upon electrocoagulation and hydrogenotrophic denitrification, respectively. The main advantages of the latter process include the exploitation of gaseous hydrogen-being harmless to both the man and the natural environment-as an electron donor and also the consumption of inorganic carbon. Besides, the growth rate of autotrophic denitrifying bacteria ensures a small biomass growth, which minimizes exploitation problems in installations of this type [4-6]. In the RECDC, the anode enables electrochemical reduction of nitrates, whereas phosphorus compounds are removed in a simultaneous 
process of electrocoagulation. The electrolytic digestion of the anode triggers the release of ions from hydroxides which are then precipitated. Afterwards, they adsorb phosphorus compounds and are accumulated in sludge which is removed from the reactor $[7,8]$.

Research is underway also into the effects of electrical current density and hydraulic retention time (HRT) on the rate of nitrates removal from the viewpoint of current efficiency (CE), which is defined as the ratio of electrical current consumed to the total energy consumption [9,10]. The term "current efficiency" encompasses both the process of electrocatalysis that involves surface reactions as well as the process of mass transfer in the system. Analyses of correlations between the current efficiency and electric current density and hydraulic retention time have demonstrated CE decrease when both these parameters were inappropriately adjusted. Due to the loss of generated hydrogen, they failed to ensure the sufficient contact time between the substrate and the biomass and caused $\mathrm{pH}$ to increase above the optimal value [11]. A study conducted by Wan et al. [12] demonstrated that the optimal current efficiency (in the function of HRT) ranged from $68 \%$ to $77 \%$ and also that more than $68 \%$ of the generated $\mathrm{H}_{2}$ was consumed by hydrogenotrophic bacteria. In turn, Ghafari et al. [13], who treated water containing $20 \mathrm{mg} \mathrm{N} / \mathrm{L}$, showed the effective HRT to range from 13.5 to $30 \mathrm{~h}$, and current density from 10 to $16 \mathrm{~mA}$. When values of both these parameters exceeded the optimal ranges, the amount of generated hydrogen was insufficient, while hydroxyl ions were produced in excess, which resulted in a diminished efficiency of nitrates removal. The CE changes along with modified work conditions, which is indicative of the impact of both the hydraulic retention time and current density on its value. High intensities of the electric current and long HRT have led to lower CE values. In turn, the higher percentage value of $\mathrm{CE}(100 \%)$ is achieved due to $\mathrm{H}_{2}$ bubbles retention on the biological carrier.

In the electrochemical process, energy consumption $(\mathrm{E})$ is highly important considering that electricity is the energy source. This can be a criterion for rationalizing process application [14].

The aim of this study was to compare the performance of rotating electrochemical and rotating electrobiological contactors, based on their current efficiency (CE) values and electric power consumption (E), during nutrients removal.

\section{Materials and Methods}

\subsection{Experimental Stand and Study Design}

The study was carried out in a laboratory scale in four single-stage rotating disk contactors (disk diameter-0.22 m; flow chamber volume-2.0 L; Figure 1)

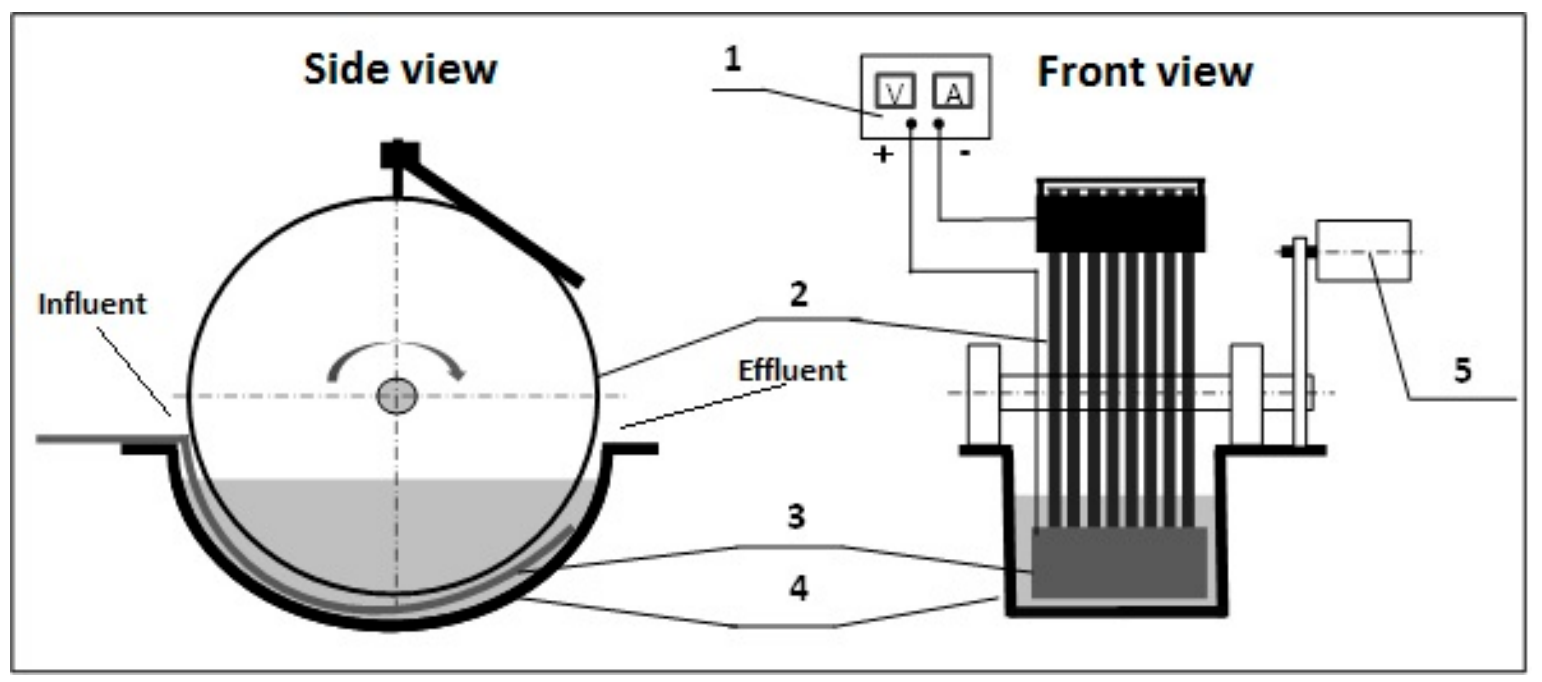

Figure 1. Scheme of an experimental model unit: 1-laboratory power supply, 2-disks (cathode), 3-anode, 4-tank, 5-electric engine [3]. 
The experiments were divided into two stages. The goal of the first stage was to calculate the current efficiency, which determined the denitrifying efficiency of nitrogen compounds removal, and the electric power consumption during the removal of a defined amount of phosphorus compounds in the rotating electrochemical disk contactor (RECDC) having disks without the immobilized biofilm. Nitrogen compounds were removed during electrochemical reduction of nitrates, and phosphorus compounds were removed during electrocoagulaction.

The second stage aimed to determine the current efficiency and electric power consumption during the removal of a defined amount of phosphorus compounds in the rotating electrobiological disk contactor (REBDC) having disks with the immobilized biofilm. Nutrient compounds were removed during hydrogenotrophic and heterotrophic denitrification, electrochemical reduction of nitrates, electrocoagulation of phosphorus compounds, and biomass growth.

In the REBDC, the cathode consisted of disks with immobilized biomass. In the RECDC, the cathode consisted of rotating disks, from which biofilm was removed periodically. An aluminum anode was placed in the flow chamber of each contactor. Both electrodes were connected to a laboratory power supply (HANTEK PPS2116A, QingDao, China) which served as a source of direct electric current and allowed maintaining its desired density. At each stage, four hydraulic retention times were tested: $4 \mathrm{~h}$, $8 \mathrm{~h}, 12 \mathrm{~h}$, and $24 \mathrm{~h}$. The following intensities of electric current were used for each hydraulic retention time: $0.35 \mathrm{~A}, 0.70 \mathrm{~A}, 1.40 \mathrm{~A}, 2.80 \mathrm{~A}$, and $5.60 \mathrm{~A}$, which corresponded to electric current density $(J)$ of: $0.63 \mathrm{~A} / \mathrm{m}^{2}, 1.25 \mathrm{~A} / \mathrm{m}^{2}, 2.50 \mathrm{~A} / \mathrm{m}^{2}, 5.00 \mathrm{~A} / \mathrm{m}^{2}$, and $10.00 \mathrm{~A} / \mathrm{m}^{2}$, respectively, defined as the intensity of electric current per the total area of the disks. The densities of electric current were selected based on literature data $[15,16]$.

\subsection{Characteristics of Wastewater Fed to Reactors}

Synthetic wastewater was used in the study. Its characteristics were similar to the wastewater from soil-less cultivation of tomatoes, which is the most common cultivation method of these vegetables, adopted after Saxena and Bassi [2] as well as Mielcarek et al. [1]. To provide appropriate conditions for biofilm development, sodium acetate was added to wastewater as a source of carbon at the second stage of the study. This allowed obtaining a C:N ratio of 0.5 , which ensured the growth of biofilm biomass and, simultaneously, allowed for autotrophic denitrification [17]. Composition of the synthetic raw wastewater used in the study is presented in Table 1.

Table 1. Synthetic raw wastewater composition and parameters.

\begin{tabular}{ccccc}
\hline Parameters & Value Mean & $\begin{array}{c}\text { Value } \\
\text { Minimum }\end{array}$ & $\begin{array}{c}\text { Value } \\
\text { Maximum }\end{array}$ & $\begin{array}{c}\text { Standard } \\
\text { Deviation * }\end{array}$ \\
\hline COD $\left(\mathrm{mg} \mathrm{O}_{2} / \mathrm{L}\right)$ & 259.5 & 217.7 & 318.0 & 39.7 \\
Total nitrogen $(\mathrm{mg} \mathrm{N} / \mathrm{L})$ & 470.3 & 445.8 & 490.3 & 14.7 \\
Nitrate $(\mathrm{mg} \mathrm{N/L)}$ & 452.5 & 429.3 & 469.4 & 14.1 \\
Ammonia nitrogen (mg N/L) & 17.8 & 16.5 & 20.9 & 2.0 \\
Nitrite (mg N/L) & 0.015 & 0.01 & 0.02 & 0.002 \\
Total phosphorus (mg P/L) & 74.4 & 48.6 & 84.5 & 10.0 \\
pH & 6.98 & 6.85 & 7.20 & - \\
Electrolytic conductivity (mS/cm) & 6.01 & 5.66 & 6.29 & 0.18 \\
Redox potential (mV) & 265.1 & 249.3 & 278.4 & 25.4 \\
\hline
\end{tabular}

* Number of samples $\mathrm{n}=20$.

The study was carried out using rotating disk contactors operated in a continuous flow mode. Wastewater was fed to reactors with Minipuls 3 peristaltic pumps (Gilson, Middleton, WI, USA).

\subsection{Analytical Procedures}

Samples were collected for analyses once a day and determined for: 
1. content of total nitrogen-using a Total Organic Carbon Analyzer TOC-L CPH/CPN with TNM-L device (Shimadzu Corporation, Kyoto, Japan), with a method of oxidative combustionchemiluminescence;

2. contents of ammonia nitrogen [PN-73/C-04576/01] with a distillation and titration method, nitrate nitrogen [PN-73/C-04576/08], and nitrite nitrogen [PN-73/C-04576/06] —using a VWR UV-3100PC Spectrophotometer (VWR International, Shanghai, China), with a colorimetric method;

3. content of total phosphorus (exact to $0.01 \mathrm{mgP} / \mathrm{L}$ ) — using a UV-VIS $5000 \mathrm{DR}$ spectrophotometer (HACH Lange, Duesseldorf, Germany), with an HACH Lange LCK 348-350 method;

4. $\mathrm{pH}$ value (exact to $0.01 \mathrm{pH}$ ), temperature (exact to $1^{\circ} \mathrm{C}$ )—using a CP-105 $\mathrm{pH}$ meter (Elmetron, Zabrze Poland); redox potential (exact to $1 \mathrm{mV}$ )—with a pH 211 meter (Hanna Instruments, Eibar, Spain); and electrolytic conductivity (exact to $0.01 \mathrm{mS} / \mathrm{cm}$ ) —using an HQ 440d multi meter (Hach Company, Loveland, CO, USA).

The analytic control of processes was begun after reactors adaptation. At stage two of the experiment, activated sludge from denitrification tanks of the Municipal Wastewater Treatment Tanks "Łyna" in Olsztyn was used as the inoculum.

At all stages of the study, results of physicochemical analyses of 20 samples (treated and raw wastewater sampled during four-week period of steady-state conditions) were used to calculate the mean values.

The efficiency of hydrogenotrophic denitrification is defined as follows $[18,19]$ :

1. current efficiency (CE) is usually employed to express the denitrification performance of bioelectrochemical reactors

$$
\mathrm{CE}=\frac{\left(C_{\mathrm{NO}_{3} \text { in }}-C_{\mathrm{NO}_{3} e f f}\right) \cdot 5-C_{\mathrm{NO}_{2 e f f}} \cdot 3}{14 \cdot I} \cdot 26.8 \cdot \frac{Q}{1000} \cdot 100(\%)
$$

where:

$\mathrm{C}_{\mathrm{NO}_{3} \text { in }}$-nitrate concentration in the influent ( $\left.\mathrm{mg} \mathrm{N} / \mathrm{L}\right)$,

$\mathrm{C}_{\mathrm{NO}_{3} e f f}$-nitrate concentration in the effluent (mg N/L),

$\mathrm{C}_{\mathrm{NO}_{2 \text { eff }}}$-nitrite concentration in the effluent $(\mathrm{mg} \mathrm{N} / \mathrm{L})$,

$Q$-flow rate $(\mathrm{mL} / \mathrm{h})$,

$I$-current applied in the reactor $(\mathrm{mA})$;

2. energy consumption (E) in phosphorus compounds removal process [14]:

$$
E=\frac{U \cdot I \cdot t}{\left(C_{\mathrm{Pin}}-C_{\mathrm{Peff}}\right) V}(\mathrm{kWh} / \mathrm{g} \text { phosphorus removed })
$$

where:

$U$-cell voltage $(\mathrm{V})$,

$I$-current applied in the reactor (A),

$t$-electrocoagulation time (h),

$\mathrm{C}_{\text {Pin }}$ - phosphorus compounds concentration in the influent (mg P/L),

$C_{\text {Peff }}$ - phosphorus compounds concentration in the effluent (mg P/L),

$V$-treated wastewater volume (L). 


\section{Results and Discussion}

\subsection{Current Efficiency}

According to results of the previous research [3], the efficiency of nitrogen and phosphorus compounds removal in RECDC was determined by both electric current density and hydraulic retention time. In the present study, the highest efficiency of nutrients removal, reaching $53.4 \%$ and 99.8\% for nitrogen and phosphorus compounds, respectively, was obtained at the highest current density and hydraulic retention time applied $\left(\mathrm{J}=10.0 \mathrm{~A} / \mathrm{m}^{2}\right.$ and $\left.\mathrm{HRT}=24 \mathrm{~h}\right)$.

The current efficiency defines the denitrifying efficiency of nitrogen compounds removal in electrochemical reactors. In the present study, CE of the electrochemical contactor decreased along with increasing density of electric current and prolonging hydraulic retention time (Figure 2).

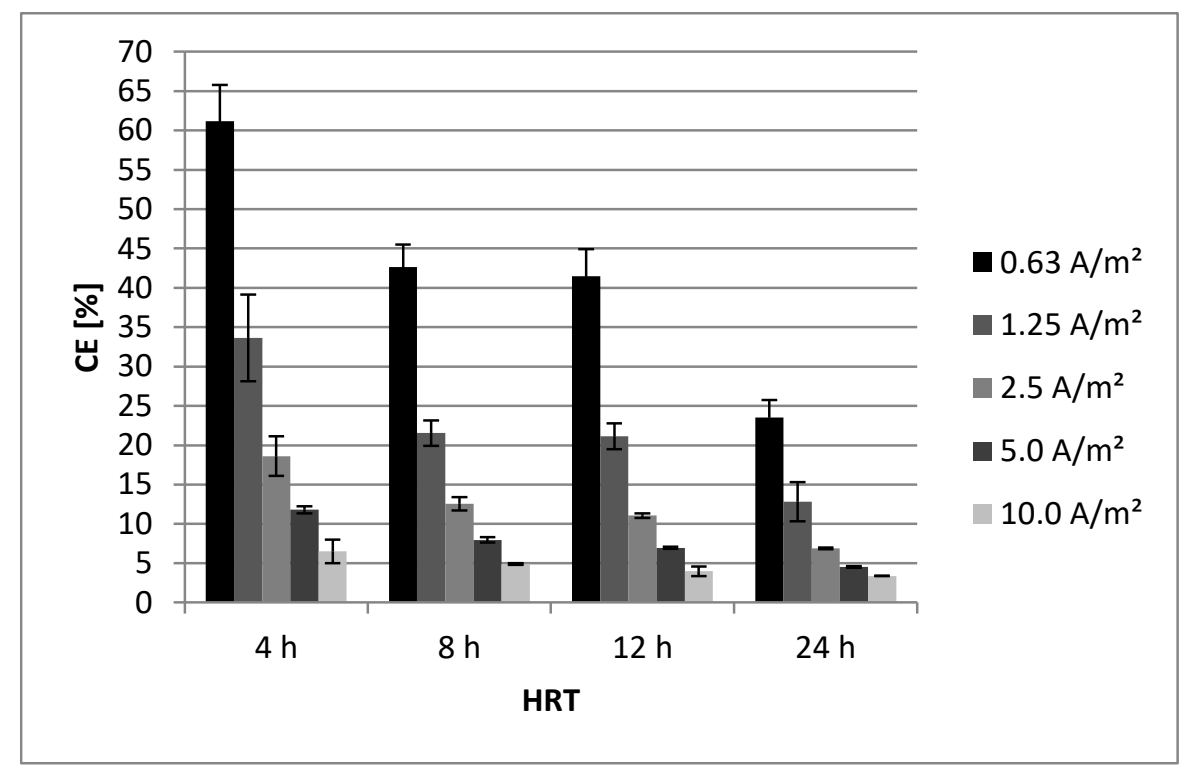

Figure 2. Current efficiency (CE) of the rotating electrochemical disk contactor (mean and standard deviation).

The highest current efficiency, reaching $61.17 \% \pm 4.59 \%$, was achieved at HRT $=4 \mathrm{~h}$ and current density of $0.63 \mathrm{~A} / \mathrm{m}^{2}$. Increasing current density at this HRT led to CE decrease. At HRT $=8 \mathrm{~h}$, the highest $\mathrm{CE}(42.6 \% \pm 2.9 \%)$ was obtained at $\mathrm{J}=0.63 \mathrm{~A} / \mathrm{m}^{2}$ and the lowest one $(4.9 \% \pm 0.1 \%)$ at $\mathrm{J}=$ $10.00 \mathrm{~A} / \mathrm{m}^{2}$. Successive extension of HRT to $12 \mathrm{~h}$ caused a further decrease in the electric efficiency of the electrochemical contactor. At this HRT and at the analyzed electrical current densities, the CE values decreased from $41.5 \% \pm 3.5 \%$ to $3.97 \% \pm 0.6 \%$. In turn, at HRT $=24 \mathrm{~h}$, the CE values reached: $23.5 \% \pm 2.2 \%, 12.8 \% \pm 2.5 \%, 6.9 \% \pm 0.1 \%, 4.5 \% \pm 0.1 \%$, and $3.4 \% \pm 0.03 \%$ for current intensities of $0.63 \mathrm{~A} / \mathrm{m}^{2}, 1.25 \mathrm{~A} / \mathrm{m}^{2}, 2.50 \mathrm{~A} / \mathrm{m}^{2}, 5.00 \mathrm{~A} / \mathrm{m}^{2}$, and $10.00 \mathrm{~A} / \mathrm{m}^{2}$, respectively.

Similar observations were made for the electrobiological contactor, the current efficiency of which was also observed to decrease along with increasing current density and prolonging hydraulic retention time (Figure 3).

The highest current efficiency, reaching $80.2 \% \pm 6.5 \%$, was achieved in REBDC during the flow of electric current with the density of $0.63 \mathrm{~A} / \mathrm{m}^{2}$ and at HRT $=4 \mathrm{~h}$. Extending hydraulic retention time at this current density led to a decrease in the electric efficiency of the contactor to $25.1 \% \pm 4.9 \%$ at $\mathrm{HRT}=$ $24 \mathrm{~h}$. Increasing electric current density to $1.25 \mathrm{~A} / \mathrm{m}^{2}$ caused a further decline in the bioelectrochemical efficiency of the contactor, from $47.66 \% \pm 1.88 \%$ at HRT $=4 \mathrm{~h}$ to $14.7 \% \pm 4.2 \%$ at HRT $=24 \mathrm{~h}$. Upon the flow of electrical current with the density of $2.50 \mathrm{~A} / \mathrm{m}^{2}$, the current efficiency decreased from $32.7 \%$ $\pm 3.9 \%$ to $10.3 \% \pm 1.7 \%$ at the lowest and the highest HRT value, respectively. At current density of $5.00 \mathrm{~A} / \mathrm{m}^{2}$, the bioelectrochemical efficiency of the contactor reached $18.5 \% \pm 4.9 \%$ at $\mathrm{HRT}=4 \mathrm{~h}$ and 
$6.4 \% \pm 0.7 \%$ at $\mathrm{HRT}=24 \mathrm{~h}$. The lowest CE $(4.6 \% \pm 0.5 \%)$ in the entire study was achieved at the flow of electric current with the density of $10.00 \mathrm{~A} / \mathrm{m}^{2}$ and at $\mathrm{HRT}=24 \mathrm{~h}$. At this current density and at the lower analyzed HRT values ( $4 \mathrm{~h}, 8 \mathrm{~h}$, and $12 \mathrm{~h}$ ), the achieved CE values were at $11.1 \% \pm 2.7 \%, 7.2 \% \pm$ $1.9 \%$, and $6.9 \% \pm 1.6 \%$, respectively.

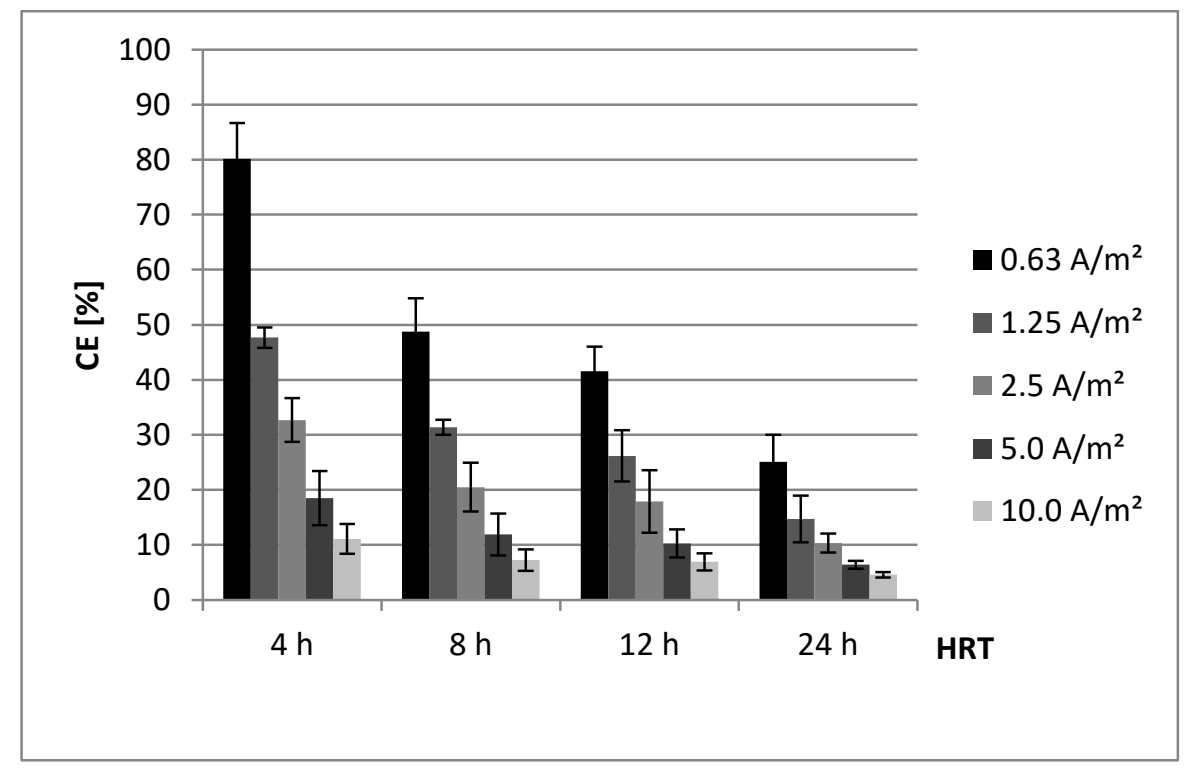

Figure 3. Current efficiency (CE) of the rotating electrobiological disk contactor (mean and standard deviation).

The REBDC was characterized by a higher efficiency of total nitrogen removal than the reactor with electrochemical reduction (RECDC). In the case of the lowest density of electric current and longer hydraulic retention times, this difference was small, whereas at higher densities the differences were significant, regardless of HRT [3].

Current efficiency is a parameter used to determine the effect of electric current density and hydraulic retention time on the rate of nitrates removal. Prosnansky and Sakakibara [11] concluded that once these two parameters are wrongly adjusted they decrease CE value due to the loss of generated nitrogen, because they fail to ensure the sufficient contact time between the substrate and the biomass and cause $\mathrm{pH}$ increase above the optimal value. In the present study, the highest $\mathrm{CE}$ value, reaching $80.2 \%$, was achieved at the lowest electric current density of $0.63 \mathrm{~A} / \mathrm{m}^{2}$ and the shortest hydraulic retention time of $4 \mathrm{~h}$. This CE is comparable with values reported by Wan et al. [12], i.e., from $68.0 \%$ to $77.0 \%$. In turn, Feng et al. [20] achieved the current efficiency of $32.0 \% \pm 0.5 \%$ in their experiment conducted in a bioelectrochemical system (BES) with sodium bicarbonate $\left(\mathrm{NaHCO}_{3}\right)$ as a carbon source. Such a low CE value, compared to results reported by other authors, is most likely due to the too small surface of the cathode which impairs effective hydrogen consumption by autotrophic bacteria. However, the too small cathode surface could not be the reason behind a low $\mathrm{CE}$ value (4.5\%) obtained in this study at $J=10.00 \mathrm{~A} / \mathrm{m}^{2}$ and HRT $=24 \mathrm{~h}$. The low CE value might have been caused by the carbon source (sodium acetate), which is consistent with findings of Feng et al. [20] who showed that using glucose as a carbon source led to $33 \%( \pm 5 \%)$ current efficiency, which could be indicative of its strong impact on the autotrophic bacteria. In turn, the use of methanol and starch as organic sources of carbon had a negative effect on the autotrophic process, as indicated by the achieved CE values of $23.0 \%$ $\pm 1.4 \%$ and $19.0 \% \pm 2.3 \%$, respectively. A study conducted by Zhou et al. [18] in a three-dimensional (3D) bioelectrochemical reactor demonstrated that it was feasible to obtain as high as $248.8 \%$ current efficiency [20], which significantly exceeded the CE values obtained in a traditional, two-dimensional (2D) bioelectrochemcial reactor (less than 100\%), like e.g., in an electrobiological rotating disk contactor. 


\subsection{Energy Consumption in Phosphorus Compounds Removal Process}

Results of the previous study [3] showed that the efficiency of phosphorus compounds removal in the REBDC exceeded 90\%, irrespective of electric current density and hydraulic retention time. At the lowest density, the efficiency of dephosphatation ranged from $90.5 \%$ to $96.2 \%$ depending on HRT, whereas over $99 \%$ efficiency of this process was achieved at higher current densities and at HRTs above $4 \mathrm{~h}$.

Electric energy consumption per load of removed phosphorus compounds was found to depend on both the electric current density and the hydraulic retention time (Figure 4). The lowest energy consumption of $0.12 \mathrm{kWh} / \mathrm{g} P$ was obtained at $J=0.63 \mathrm{~A} / \mathrm{m}^{2}$ and HRT $=4 \mathrm{~h}$. At this $J$ value and HRTs of $8 \mathrm{~h}, 12 \mathrm{~h}$, and $24 \mathrm{~h}$, the obtained $E$ values were as follows: $0.22 \mathrm{kWh} / \mathrm{g} \mathrm{P}, 0.31 \mathrm{kWh} / \mathrm{g} \mathrm{P}$, and $0.64 \mathrm{kWh} / \mathrm{g} \mathrm{P}$, respectively. Increasing current density to $1.25 \mathrm{~A} / \mathrm{m}^{2}$ led to an increase in electric power consumption. Its value increased proportionally to the hydraulic retention time and ranged from $0.21 \mathrm{kWh} / \mathrm{g}$ P to $1.24 \mathrm{kWh} / \mathrm{g}$ P. At current density of $2.50 \mathrm{~A} / \mathrm{m}^{2}$, the $E$ values increased from $0.42 \mathrm{kWh} / \mathrm{g}$ $\mathrm{P}$ to $2.45 \mathrm{kWh} / \mathrm{g} \mathrm{P}$ at HRTs ranging from $4 \mathrm{~h}$ to $24 \mathrm{~h}$. Increasing current density to $5.00 \mathrm{~A} / \mathrm{m}^{2}$ contributed to a successive increase in the electric energy consumption. At the highest current density and HRT tested, i.e., at $10.00 \mathrm{~A} / \mathrm{m}^{2}$ and HRT $=24 \mathrm{~h}$, the consumption of electric power in the phosphorus compounds removal process was the highest and reached $E=9.43 \mathrm{kWh} / \mathrm{g} \mathrm{P}$. At this current density and shorter HRTs, the $E$ values were at $1.50 \mathrm{kWh} / \mathrm{g} \mathrm{P}, 3.02 \mathrm{kWh} / \mathrm{g} \mathrm{P}$, and $4.43 \mathrm{kWh} / \mathrm{g} P$ for HRTs of $4 \mathrm{~h}$, $8 \mathrm{~h}$, and $12 \mathrm{~h}$, respectively.

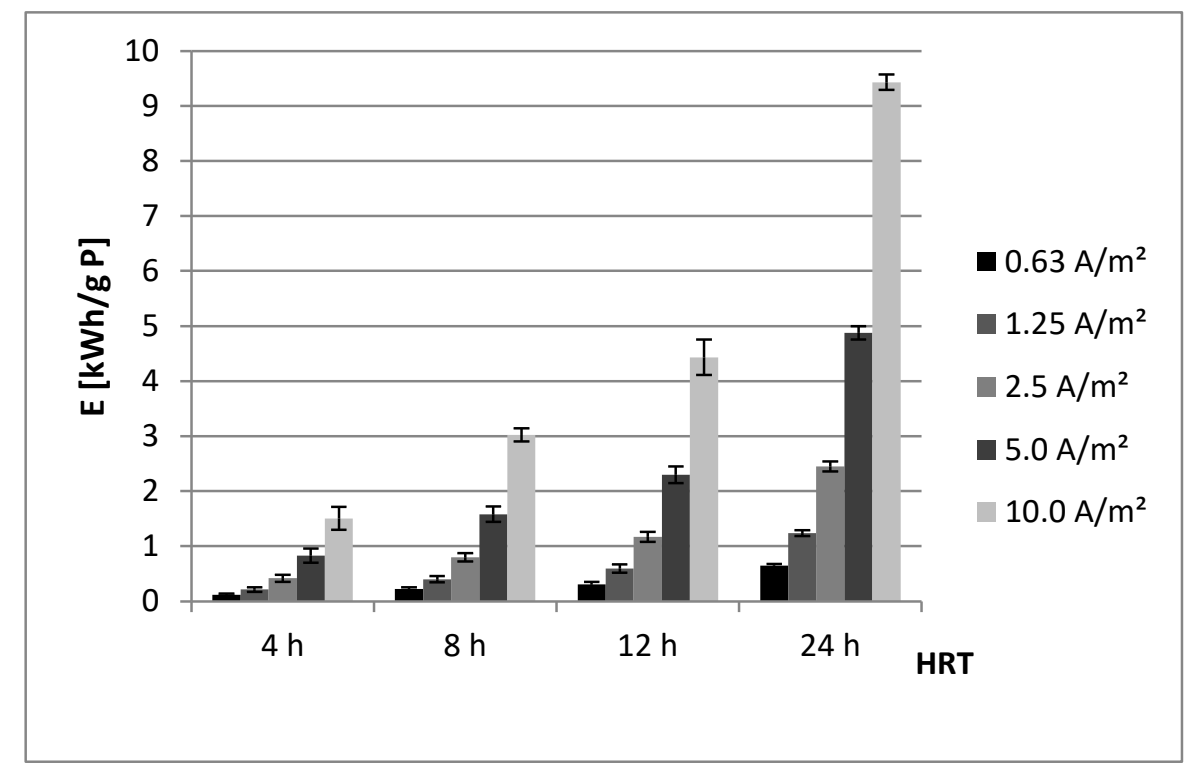

Figure 4. Influence of current density and hydraulic retention time (HRT) on electric power consumption in the removal of phosphorus compounds in the rotating electrochemical disk contactor (mean and standard deviation).

In the rotating electrobiological disk contactor, energy consumption in the process of phosphorus compounds removal also increased along with increasing values of current density and hydraulic retention time (Figure 5). Its highest value $(9.46 \mathrm{kWh} / \mathrm{g} \mathrm{P})$ was obtained at $J=10.00 \mathrm{~A} / \mathrm{m}^{2}$ and HRT $=$ $24 \mathrm{~h}$. At the same electric current density and $\mathrm{HRT}=4 \mathrm{~h}$, its value reached $E=4.44 \mathrm{kWh} / \mathrm{g}$ P. The lowest electric energy consumption in the process of phosphorus compounds removal $(E=0.10 \mathrm{kWh} / \mathrm{g} \mathrm{P})$ was obtained at the lowest density of electric current $\left(J=0.63 \mathrm{~A} / \mathrm{m}^{2}\right)$ and the shortest hydraulic retention time $(\mathrm{HRT}=4 \mathrm{~h})$ tested. At longer HRTs and the same $J$ value, electric energy consumption reached: $0.20 \mathrm{kWh} / \mathrm{g} \mathrm{P}, 0.29 \mathrm{kWh} / \mathrm{g} \mathrm{P}$, and $0.61 \mathrm{kWh} / \mathrm{g} \mathrm{P}$ for HRTs of: $8 \mathrm{~h}, 12 \mathrm{~h}$, and $24 \mathrm{~h}$. Increasing electric current density to $1.25 \mathrm{~A} / \mathrm{m}^{2}$ increased power consumption from $0.20 \mathrm{kWh} / \mathrm{g} \mathrm{P}$ to $1.18 \mathrm{kWh} / \mathrm{g} \mathrm{P}$ at the analyzed HRTs. During the flow of electric current with the density of $2.50 \mathrm{~A} / \mathrm{m}^{2}$, energy consumption 
increased from $0.39 \mathrm{kWh} / \mathrm{g} \mathrm{P}$ to $2.36 \mathrm{kWh} / \mathrm{g} \mathrm{P}$ at HRT ranging from $4 \mathrm{~h}$ to $24 \mathrm{~h}$. Increasing current density to $5.00 \mathrm{~A} / \mathrm{m}^{2}$ caused a successive increase in energy consumption from $0.76 \mathrm{kWh} / \mathrm{g} \mathrm{P}$, through $1.52 \mathrm{kWh} / \mathrm{g} \mathrm{P}$ and $2.26 \mathrm{kWh} / \mathrm{g}$ P to $4.74 \mathrm{kWh} / \mathrm{g} \mathrm{P}$ at HRTs of $4 \mathrm{~h}, 8 \mathrm{~h}, 12 \mathrm{~h}$, and $24 \mathrm{~h}$.

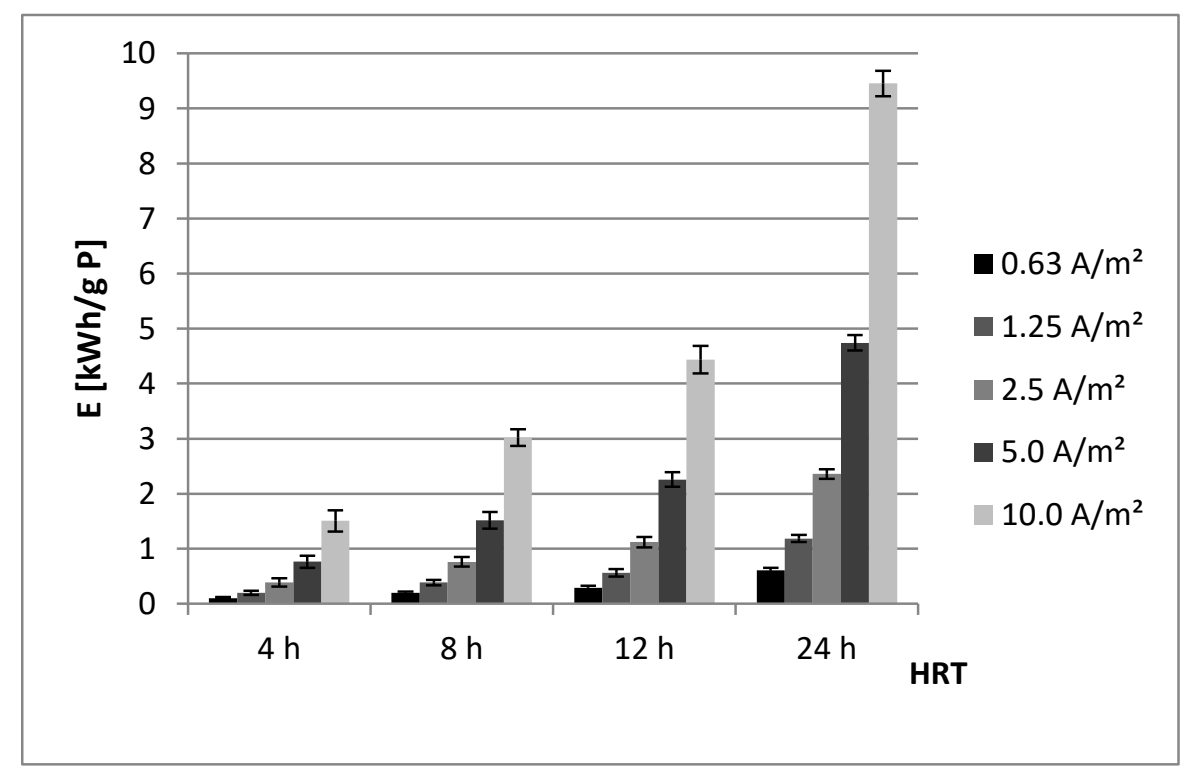

Figure 5. Influence of current density and HRT on electric energy consumption in the removal of phosphorus compounds in the rotating electrobiological disk contactor (mean and standard deviation).

\section{Conclusions}

The study showed a decrease in the current efficiency of the electrochemical contactor with an increase of the electric current density and hydraulic retention time. The current efficiency was the highest in the contactor operated at a hydraulic retention time of $4 \mathrm{~h}$ and current density of $0.63 \mathrm{~A} / \mathrm{m}^{2}$ $(61.17 \% \pm 4.59 \%)$, whereas the lowest in the contactor operated at a hydraulic retention time of $24 \mathrm{~h}$ and current density of $10.00 \mathrm{~A} / \mathrm{m}^{2}(3.4 \% \pm 0.03 \%)$. The study demonstrated also that the electric energy consumption in the removal of a defined load of phosphorus compounds depended on both the current density and the hydraulic retention time. Its lowest value $(0.12 \mathrm{kWh} / \mathrm{g} \mathrm{P})$ was obtained at $J=0.63 \mathrm{~A} / \mathrm{m}^{2}$ and HRT $=4 \mathrm{~h}$, whereas the highest one $(9.43 \mathrm{kWh} / \mathrm{g} \mathrm{P})$ at $J=10.00 \mathrm{~A} / \mathrm{m}^{2}$ and HRT $=24 \mathrm{~h}$.

Similar tendencies were observed in the electrobiological contactor. In the contactor operated at current density of $0.63 \mathrm{~A} / \mathrm{m}^{2}$ and an HRT of $4 \mathrm{~h}$, the current efficiency was the highest $(80.2 \% \pm 6.5 \%)$, while in the contactor operated at $10.00 \mathrm{~A} / \mathrm{m}^{2}$ and an HRT of $24 \mathrm{~h}$, it was the lowest $(4.6 \% \pm 0.5 \%)$. Electric energy consumption in the process of phosphorus compounds removal increased along with increasing density of electric current and prolonging hydraulic retention time. The highest electric energy consumption $(9.46 \mathrm{kWh} / \mathrm{g} \mathrm{P})$ was achieved at $J=10.00 \mathrm{~A} / \mathrm{m}^{2}$ and HRT $=24 \mathrm{~h}$, whereas the lowest one $(0.10 \mathrm{kWh} / \mathrm{g} \mathrm{P})$ at $J=0.63 \mathrm{~A} / \mathrm{m}^{2}$ and an $\mathrm{HRT}=4 \mathrm{~h}$.

The study showed that increasing the current density and hydraulic retention time increased electric energy consumption during phosphorus compounds removal and simultaneously lowered current efficiency in both the electrochemical and the electrobiological contactor.

The current efficiency values were higher in the electrobiological contactor than in the electrochemical one. Combining biological processes with electrochemical processes in the electrobiological contactor resulted in almost $20 \%$ higher current efficiency in the contactor operated at the density of $0.63 \mathrm{~A} / \mathrm{m}^{2}$ and $\mathrm{HRT}=4 \mathrm{~h}$.

Author Contributions: Conceptualization, J.R.; data curation, J.R. and A.M.; formal analysis, K.B.; methodology, J.R. and W.J.; resources, K.B.; supervision, W.J.; visualization, J.R. and A.M.; all authors have read and approved the final manuscript. All authors have read and agreed to the published version of the manuscript 
Funding: This research was funded by Polish National Agency for Academic Exchange under the International Academic Partnerships Programme from the project "Organization of the 9th International Scientific and Technical Conference entitled Environmental Engineering, Photogrammetry, Geoinformatics-Modern Technologies and Development Perspectives" and Project No. 18.610.008-300 of the University of Warmia and Mazury in Olsztyn, Poland

Conflicts of Interest: The authors declare no conflict of interest.

\section{References}

1. Mielcarek, A.; Rodziewicz, J.; Janczukowicz, W.; Dobrowolski, A. Analysis of wastewater generated in greenhouse soilless tomato cultivation in central Europe. Water 2019, 11, 2538. [CrossRef]

2. Saxena, P.; Bassi, A. Removal of nutrients from hydroponic greenhouse effluent by alkali precipitation and algae cultivation method. J. Chem. Technol. Biotechnol. 2013, 88, 858-863. [CrossRef]

3. Rodziewicz, J.; Mielcarek, A.; Janczukowicz, W.; Jóźwiak, T.; Struk-Sokołowska, J.; Bryszewski, K. The share of electrochemical reduction, hydrogenotrophic and heterotrophic denitrification in nitrogen removal in rotating electrobiological contactor (REBC) treating wastewater from soilless cultivation systems. Sci. Total Environ. 2019, 683, 21-28. [CrossRef] [PubMed]

4. Krzemieniewski, M.; Rodziewicz, J. Nitrogen compounds removal in a rotating electrobiological contactor. Environ. Eng. Sci. 2005, 22, 816-822. [CrossRef]

5. Kłodowska, I.; Rodziewicz, J.; Janczukowicz, W.; Cydzik-Kwiatkowska, A.; Parszuto, K. Effect of citric acid on the efficiency of the removal of nitrogen and phosphorus compounds during simultaneous heterotrophic-autotrophic denitrification (HAD) and electrocoagulation. Ecol. Eng. 2016, 95, 30-35. [CrossRef]

6. Kłodowska, I.; Rodziewicz, J.; Janczukowicz, W.; Cydzik-Kwiatkowska, A.; Rusanowska, P. Influence of carbon source on the efficiency of nitrogen removal and denitrifying bacteria in biofilm from bioelectrochemical SBBRs. Water 2018, 10, 393. [CrossRef]

7. Rodziewicz, J.; Krzemieniewski, M. Phosphorus compounds removal in a rotating electro-biological contactor. Pol. J. Nat. Sci. 2006, 20, 403-412.

8. Janczukowicz, W.; Krzemieniewski, M.; Pesta, J.; Rodziewicz, J. Studies on the use of bioelectric tape filter for phosphorus compounds removal from wastewater. Nat. Sci. 2001, 9, 317-324.

9. Cast, K.L.; Flora, J.R.V. An evolution of two cathode materials and the impact of copper on bio-electrochemical denitrification. Water Res. 1998, 32, 63-70. [CrossRef]

10. Chen, G. Electrochemical technologies in wastewater treatment. Sep. Purif. Technol. 2004, 38, 11-41. [CrossRef]

11. Prosnansky, M.; Sakakibara, Y.; Kuroda, M. High-rate denitrification and SS rejection by biofilm electrode reactor (BER) combined with microfiltration. Water Res. 2002, 36, 4801-4810. [CrossRef]

12. Wan, D.; Liu, H.; Liu, R.; Qu, J. Study of a combined sulfur autotrophic with proton-exchange membrane electrodialytic denitrification technology: Sulfate control and $\mathrm{pH}$ balance. Bioresour. Technol. 2011, 102, 10803-10809. [CrossRef] [PubMed]

13. Ghafari, S.; Hasan, M.; Aroua, M.K. Nitrate remediation in a novel upflow bioelectrochemical reactor (UBER) using palm shell activated carbon as cathode material. Electrochim. Acta 2009, 54, 4164-4171. [CrossRef]

14. Hooshmandfar, A.; Ayati, B.; Khodadadi Darban, A. Optimization of material and energy consumption for removal of Acid Red 14 by simultaneous electrocoagulation and electroflotation. Water Sci. Technol. 2016, 73, 192-202. [CrossRef] [PubMed]

15. Islam, S.; Suidan, M.T. Electrolytic denitrification: Long term performance and effect of current intensity. Water Res. 1998, 32, 528-536. [CrossRef]

16. Zhao, Y.; Feng, C.; Wang, Q.; Yang, Y.; Zhang, Z.; Sugiura, N. Nitrate removal from groundwater by cooperating heterotrophic with autotrophic denitrification in a biofilm-electrode reactor. J. Hazard. Mater. 2011, 192, 1033-1039. [CrossRef] [PubMed]

17. Rodziewicz, J.; Janczukowicz, W.; Mielcarek, A.; Filipkowska, U.; Kłodowska, I.; Ostrowska, K.; Duchniewicz, S. Anaerobic rotating disc batch reactor nutrient removal process enhanced by volatile fatty acid addition. Environ. Technol. 2015, 36, 953-958. [CrossRef] [PubMed]

18. Zhou, M.; Fu, .W.; Gu, H.; Lei, L. Nitrate removal from groundwater by a novel three-dimensional electrode biofilm reactor. Electrochim. Acta 2007, 52, 6052-6059. [CrossRef] 
19. Zhou, M.; Wang, W.; Chi, M. Enhancement on the simultaneous removal of nitrate and organic pollutants from groundwater by a three-dimensional bio-electrochemical reactor. Bioresour. Technol. 2009, 100, 4662-4668. [CrossRef] [PubMed]

20. Feng, H.; Huang, B.; Zou, Y.; Li, N.; Wang, M.; Yin, J.; Cong, Y.; Shen, D. The effect of carbon sources on nitrogen removal performance in bioelectrochemical systems. Bioresour. Technol. 2013, 128, 565-570. [CrossRef] [PubMed]

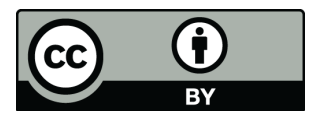

(C) 2020 by the authors. Licensee MDPI, Basel, Switzerland. This article is an open access article distributed under the terms and conditions of the Creative Commons Attribution (CC BY) license (http://creativecommons.org/licenses/by/4.0/). 